\title{
About Increase of Efficiency of Tax Planning: the Theorist - Methodological and Practical Aspects
}

\begin{abstract}
Are investigated the theorist - methodological bases of tax planning on macro and microlevels. The debatable review and the analysis of opinions Russian and foreign scientists concerning essence of the concept "tax planning" is carried out. Research criteria of classification of tax planning also are specified. On the basis of system approach need of consideration of tax planning of the income of corporations as the integration process consisting in streamlining of its economic activity according to strategy of its development on the basis of observance of the tax current legislation is shown. Expediency of the formulation in the Russian tax legislation of the concept "tax planning" is reasoned. Institutional bases of increase of efficiency of tax planning in the conditions of permanent economy are revealed

Keywords: tax planning, classification, theory and methodology, institutional conditions, corporations, foreign researchers, Russian scientists, tax privileges, organization, minimization.
\end{abstract}

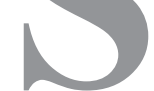

ocial and economic growth, on a scale of the whole country and its separate regions, depends cardinally upon the tax policy of the state. The provision of the efficiency of tax policy realization represents the most up-to-date problem at the present time in the Russian Federation. A special place in the taxation process belongs to tax planning.

On one side, tax planning serves as an object of scientific research, representing a relatively new direction for Russian finance science, and on the other side it represents an area of practical activity. Tax planning can and should be considered both from the perspective of the state and local government bodies represented by their authorized agencies, and from the perspective of a certain economic entity, i.e. on macro- and
micro-levels.In spite of positive movements they pay inadequate attention to theoretical and methodological aspects of tax planning in Russia. Therefore, it will be logical to begin with a more precise definition of tax planning and the criteria of its classification.

A famous Russian scientist, Doctor of Economics, Professor T.F. Yutkina, was one of the first researchers who introduced the concept of state "tax management" and "tax planning" as its component [1]. Such authors as M. V. Romanovsky and O. V. Vrublevskaya pointed out the necessity and timeliness ofthe separation of problematics, connecting with the planning of the taxation process as an individual direction, as well as the establishment of methodological and methodical fundamentals of this

MUSAEVA Khaibat Magomedtagirovna - FGBOU VPO “Dagestan State University".

Russian Federation, 367025, Republic of Dagestan, Makhachkala, Gadzhiev St. 43, 8988-213-22 - 55,

[xaibat27@rambler.ru] 
process in the form ofan entire integrated system. In their opinion, practicability of its separation is determined by the fact that due to disunity of the governmental bodies dealing with management of tax processes, certain discrepancies in statutory and regulatory support of taxation - between economic, social and politicalpurposes of the state and the capability of financial support for their achieving- appear [2].

Some authors (Karbushev G. I., Zimin V.M.) consider that tax planning should be regarded as "methods of selection of the best configuration of legal forms of relations and possible variations of their interpretation in the frames of effective tax legislation, as well as methods of more precise forecasting of in-payments received from certain taxpayers, from taxpayers in the aspect of certain types of taxes and receipt of tax payments to all items of budget in general" [3].

In the author's opinion, a shift of conceptions of tax planning and forecasting appears in this definition. Besides, it does not uncover the main purpose of tax planning in the financial and economic policy of a modern state. There are other definitions of tax planning, revealing its economic substance and essence from different sides. For example, tax planning means selection between different variations of performance of tax activity and allocation of assets [4].

The Great Economy Encyclopaedia interprets tax planning as choosing between different variants of performance of a legal entity's activity and allocation of its assets aimed to the achievement of as low a level of tax liabilities appeared upon this as possible [5].The Dictionary of Business Terms by D. Friedman defines tax planning as "systematic analysis of different tax alternatives aimed to minimization of tax liabilities in current and future periods' [6].Such foreign scientists as E. Bodie and R. Merton hold the same definition [7].

The definitions represented above characterize a concept of tax planning mainly in the "restricted" sense, i. e. the content of tax planning is uncovered only at the level of an economic entity.

Russian research scientists A.I. Ponamarev and T. V. Ignatova consider that tax planning at the macrolevel "represents estimation of tax potential and returns of taxes and levies to the budget system, and is performed by state and governmental bodies based on forecasting of social and economic development of the Russian Federation and its constituent entities, representing a system of indicators and main parameters for directions of social and economic development" [8].In the opinion ofDoctor ofEconomics, Professor of the Financial University under the Government of the Russian Federation, L. I. Goncharenko, the purpose of the planning of tax returns is the achievement of the highest level of mobilization of taxes and levies to the budget system [9].

Tax planning, especially in the context of federal and regional levels, is preceded by tax forecasting. The specific content of the tasks of tax planning and forecasting depends to a large extent upon the scale of the subject of management in regard to which they are set and being solved (taxation on the national scale or in the frames of a separate region). Reasoning from this fact, it is required to distinguish tax forecasting and planning at federal and sub-national levels.

Tax planning at the macro-level possesses an essential singularity, lying in directive and indicative forms of performance. In fact, on one side, budgetary tax assignments acquire a status of law after they are approved by the legislative body of the Russian Federation or regional representative bodies; on the other side, as distinct from traditional directive assignments, they don't have a specific address form that makes it necessary to look for other methods ofregulation and control over the fulfilment of budgetary and tax assignments. Itis necessary to note that this aspect of the problem of organization of the efficient mechanism of the management of tax relations hasnot yet found appropriate reflection in science and practice.

Measures for the improvement of supervising work of taxation authorities, as well as for the improvement of the general economic situation in the country, in the constituent entities of the Russian Federation and the creation of necessary conditions for the development ofentrepreneurial business that represents a basis for planning of ad- 
ditional returns of taxes, are being designed in the process of tax planning. From the perspective of the taxation authorities, tax planning (based on the task of completeness ofexecution of the revenue side of the budget) should take into account the main directions oftax policy of the state, the results of analysis of data for the course of performance of current tax liabilities, the shortfall in the budget income due to application oftax, and the levy relief stipulated by the state.

In such a context, determination of the taxation base should be the initial component of tax planning.It is practicable to perform a calculation of the taxation base in regional terms, with the account of industrial structure by each type of tax. Upon this, tax planning should be based on the results of the analysis of fulfilment of current tax liabilities, as well as monitoring and forecasting of the macro-economic situation in the regions. Such situations can be explained not so much by the efficiency of the work of the taxation authorities, as by the existing taxation base and corresponding movement of financial flows that predetermine the necessity to apply an individual approach while calculating a taxation base for each region.

In the process of tax planning at the macrolevel, they not only implement fiscal assignments, but lay the basis for optimization of tactics and strategy of tax regulation and control as well. In modern conditions, tax science has not created special methods of planning of amounts of tax returns to the budget. In practice they apply generally known and much-used traditional methods in the process of tax planning. Application of these methods is justifiable, because they are unified and do not depend upon specifics of the processes under research. At the same time, one should also apply specific approaches to detection of common tax factors, and to drafting of perspective tax conceptions on their base in the process of tax planning.

The necessity of application of different methods and procedures of tax planning in practice is caused largely by multiplicity of taxes and their different impact on the factors of production. This was mentioned by R. Musgrave: "Different taxes impact on norms of savings and investments and therefore on capital formation in different ways. Increase or decrease of capital will result in change of factor revenues and therefore in distribution of revenues in the economy" [10].

Thus, we can conclude that tax planning at the macro-economic level does not represent mechanical determination of the amount of future returns to the budgets of the corresponding governmental bodies. It is a process of detection and mobilization of reserves existing in the economy for the solving of nationwide, regional and local tasks in tactical and strategic aspects.

Based on the above stated information, let usoffer a definition of sub-national tax planning which defines its methodological essence. Tax planning on the level of constituent entities of the Russian Federation (sub-national level) is a process of determination of economically feasible amounts of tax returns, detection and mobilization of reserves, for the increase of revenues of regional and local budgets in conditions of modern financial policy, pursued by governmental authorities and local administration bodies. Similar to tax planning on a federal nationwide scale, tax planning at a sub-national level allows the determining of expense items of the budget in such amountsthat are required for the fulfilment of social, economic and other programmes of regional and local authorities, avoiding budget deficit upon this.

The author considers that a concept of "tax planning" should be recognized in the Russian tax legislation, in the Tax Code of the Russian Federation in particular, for improvement of the quality of forecasting of tax revenues. Determination of the essential features of this component of the economy in tax legislation has a substantial significance for formation of a concept of its estimation and state control, including tax control, over the generation of budget revenues.

While establishing an efficient system of tax planning at the macro-level, it is important to receive high-quality information which would be reliable, well-timed and which would comply with the requirements placed on it. To do this, it is necessary to successfully implement such stages as the setting of purposes, the formation of reli- 
able indicators and the creation of high-quality information gathering systems. In developed nations, planning beginswith the determination of purposes and tasks and the setting of qualitative and quantitative indicators for the achievement of these purposes [11].

At the present stage of the Russian Federation, distinct methodological approaches for the establishment and functioning of the tax planning system at the macro-level have not yet worked out the consequence of what is a systematic discrepancy between planned and actual indicators of mobilization of tax returns to the budgets of different levels. So, according to the official information of the Federal Tax Service of the Russian Federation in 2010, the federal budget received 3,207.2 billion roubles from tax returns; that is an increase of $28 \%$ in comparison with 2009. However, in comparison with 2008 , the amount of received taxes is less - by $10 \%$.Budgetary assignments for the mobilization of taxes were fulfilled by only $97.3 \%$ [12].Concerning the fact that the amount of tax returns to the federal budget in 2010 did not reach the level of 2008, we can agree with the official position of the Federal Tax Service of the Russian Federation in regard to the lower oil price (average price: 2008-94USD per barrel; 2010-77USD per barrel; oil price in 2009 was 58 USD per barrel). However, systematic discrepancies between planned and actual indicators of the execution of budget assignments of both the federal budget and the budgets of constituent entities of the Russian Federation give evidence that the instruments of tax planning require improvement.

A similar situation can be observed in many regions of the Russian Federation as well. In particular, reported data of the Ministry of Finance of the Republic of Dagestan give evidence that in 2012, budget assignments for mobilization of tax returns to the consolidated budget of the Republic were fulfilled by only $95.0 \%$.In particular in regard to: excise taxes $-84.37 \%$; tax on profit of organizations - $93.81 \%$; tax on property of organizations - 93.35\%; in regard to personal income tax and tax on natural resources production, these figures were over-fulfilled; by $106.5 \%$ and $104.2 \%$ respectively. Due to non-fulfilment of planning assignments, the budget losses of the consolidated budget of the Republic of Dagestan amounted to 993.5 million roubles

Thus, informational and statistical analysis shows systematic under-fulfilment of budget assignments in regard to certain items and over-fulfilment in regard to other ones. Non-compliance between forecasting and actual indicators (in addition to the other factors) can be explained by the establishment of budget assignments, without the highest possible consideration of factors impacting on the formation of the taxation base because of the non-availability of a scientifically grounded methodical procedure of the actual determination of a taxation base.

To confirm the validity of our conclusion we made statistical sampling and undertook an appropriate study for the year of 2003. Analysis of fulfilment of budget assignments for mobilization of tax returns to the budget of the Republic of Dagestan for the above- mentioned period identified some discrepancies between planning and budgetary indicators of fiscal performance as well.So, assignments for mobilization of personal income tax to the budget were fulfilled by $105.2 \%$ : tax on natural resources production $-118.2 \%$, tax on profit of organizations $88.3 \%$, excise tax on excise goods - 78.2\%, licence and registration levies - $97.7 \%$, tax on land $-42.9 \%$, water tax $-73.8 \%$, and transport $\operatorname{tax}-36.7 \%$.

By virtue of the objective uncertainty of forecasts of tax revenues, differences between projected and actual scopes of mobilization are inevitable. As a rule, such discrepancies are the consequence of inaccuracies contained in economic reports used for analysis; unforeseen changes in legislation; changes in the system of tax administration and degree of taxpayers' compliance with the law; other reasons of economic, organizational and methodical nature. However, fulfilment of planning assignments depends not only on the efforts of the authorized bodies and the economic situation in the region, but also on how real and feasible the positions of the plan are, and how accurate the calculations and forecasts taken as a basis for its development are. 
In connection with the above-listed information, the improvement of methodological and methodical fundamentals of tax planning and strengthening of its scientifically grounded component comes at an opportune time in the modern Russian Federation.Regarding this, development of a new approach to quantitative estimation of budgetary assignments on the basis of a real taxation base and appropriate tax potential of constituent entities of the Russian Federation has significant importance.

Unfortunately, indicators of tax potential and fiscal performance, as well as methodical procedure of calculation of the taxation base, on the basis of which assignments for the flow of revenues to the budgetary system are being determined, have not represented acknowledged economic and statistic indicators until nowRussian Federation.

The undetermined status of these indicators mitigates the efficiency of the taxation and budgetary process; however, for example, reduction of the average indicator of fiscal performance, even by a few percent, results in a significant loss of taxes. This is why indicators of tax potential and fiscal performance, as well as factors impacting on the fiscal performance and methods of their estimation, should be considered as full instruments of tax and budgetary planning and statistical accounting.

Classification criteria of tax planning play an important role in the development of theoretical and methodological fundamentals of tax planning. Classification of tax planning should be grounded on a general theory of classification and take into account the gnoseological roots of this conception. Tax planning is a component, an element of a system of general economic planning; that's why characteristic features of the latter must be immanently present in the former.

Interacting with other components of the integral system, tax planning uses all the features inherent in general economic planning. While examining the classification of tax planning it is necessary to remember, in the first place, the logic and construction of a chain of the best methods of achievement of the stated purposes and, in the second place, the time frames limiting, on one part, the setting of impossible tasks and purposes, and on the other part acting as indicators of the efficiency of planned actions by comparison of forecasting and actual results [13].

Based on the above-stated classification of tax planning as a process of development, and further control over the progress of implementation of the tax plan and its correction in accordance with the changing institutional conditions, it can be constructed only on the basis of the parameters of the term structure of tax planning. As timeframes of achievement of the purposes differ from each other, the logic and structure of the sequence ofevents of the tax planning process comply with general theoretical rules and are not liable to differentiation. Therefore it can be stated that tax planning is management activity directed to the achievement of short-term, mid-term and long-term (strategic) purposes (results), i.e. tax planning is divided into: operative, tactical and strategic tax planning, performed on macro and micro-levels.

The author doesn't share the opinion of researchers about the multiplicity of criteria of classifications of tax planning. For example, D. N. Tikhonov considers that there are two criteria of differentiation of types of tax planning: the legitimacy of actions of a taxpayer, i.e. how the actions of a taxpayer comply with legislation, and the degree of a tax burden, whether he (she) pays taxes, taking no measures directed to decrease taxation or minimize taxes by any way [14].Upon simultaneous use of these criteria D. N. Tikhonov obtains three types of tax planning: classic tax planning, optimization tax planning and vulgar (illegal) tax planning.

Foreign researcher P. Valente separates aggressive tax planning additionally. In accordance with the definition of the researcher, aggressive tax planning includes application of artificial operations or structures, with use ofan imbalance between tax jurisdictions, with an effect of erosion of taxation rules and a loss of tax returns in the country of location or residence of the taxpayer [15]. German researcher R. Busse also supports this approach to classification of tax planning [16]. 
Authors of the classification given above, like many other researchers, define tax planning, not exactly substituting its essence by contentrelated characteristics. In general, planning is a data reduction process aimed at substantiation of the forthcoming actions; it cannot be optimization or classic, legal or illegal.

The planning process complies with general philosophical and methodological principles. In this sense it is unified and uniform. For example, one cannot say that the planning process is illegal (vulgar); you can estimate planned actions from the perspective of legitimacy. These actions are nothing more than content of planning, and they can be estimated from different points of view. That's why it is necessary to speak in this case not about classification of tax planning, but about grouping of planned actions (measures, methods, ways) in accordance with certain characteristics common to components of the whole group.

Short-term tax planning serves as a basis for drafting of budgets for corresponding levels of authorities for the next (succeeding) year. Indicators of social and economic forecasts of the country for the next year, as well as analysis of tax returns for the current year, both in the whole and for separate taxes, serve as a basis for such planning. Short-term planning is performed directly by the Ministry of Finance of the Russian Federation and financial authorities for corresponding budgets, upon the direct participation of taxation and other economic bodies.

One should also take into account possible probabilistic deviation of the most important social and economic indicators in the next year, as well as the influence of the political situation in the community. Regarding this, the amounts of both all the taxes in whole, and their certain types, should be analysed and determined in detail. In forward planning, however, as a rule, there is no division into tax types; it covers all the taxes in whole.Both current and forward planning are based simultaneously on the forecast of social and economic development of the country for the corresponding period and serve as a basis for determination of the main characteristics of this forecast. In particular, the amounts of state investments for the planned period and, therefore, economic growth rates, for instance, depend on fiscal performance and the amount of tax returns. The dependence of the country's social and economic development on the forecast of the amounts of tax returns is much higher in the forward planning. Tax planning is used here as a method of economic foresight.

Thus, we can summarize that based on the understanding of the fact that tax planning represents an economic construction, the abstract process of forecasting of certain actions of tax planning is divided into operative, tactical and strategic, which can be performed on macro and micro-levels.Another classification is possible only from the perspective of its practical destination, when attributive features of the measures contained in the taxation plan, subjects planning tax efficiency measures, territorial and jurisdiction characteristics of these measures, and objects affected by the planned measures, are used as a classification basis.

The formation and development of market relations focused the attention of Russian scientists on the research of problems of tax planning at the micro-level, i.e. in activities of economic entities. The results of these researches found their way into the works of Russian scientists.

Russian scientists E. S. Vylkova [17], S.A. Guskov [18], E. Yu.Zhidkova [19], D.A. Melnik [20], A. I. Ponomarev [8], B.A. Ragozin [21], E. Yu. Sidorova [22], K. S. Seliutin [23],, D. N. Tikhonov [14], D. G. Chernik [24], performed significant research in the area of tax planning of economic entities.

The availability of relief in the effective regulatory acts of the state and their practical use represents a basis of tax planning at the microlevel.Surely, questions of tax relief functioning are tightly linked with the problem of the estimation of their effectiveness. In the cases when the relief does not have a social return or is economically inefficient, then such relief cannot play its role to the full extent, as the most mobile instrument of tax regulation. Additionally, inefficient relief results in not only direct loss of budget revenues, but also in such phenomena as the decrease of- 
competitiveness of goods (works, services), and market motivation of economic entities not using such relief, slackening of the rates of economic growth, intensification of social inequality and tension in the community, etc. The estimation of effectiveness involves, as a rule, comparison of the result of one or another action with the expenses required for its performance.To improve the effectiveness of preferential taxation, many Russian and Ukrainian scientists (I. A. Mayburov, Yu.B.Ivanov, I.A. Panskov, L.L. Tarangul) propose to account them both in decreasing budget revenues and in a separate item on the expense side of the budget [25].In world practice such a conception is referred to as a "conception of tax expenses of the budget". Academic literature recognizes the fact that programmes of tax expenses can be more efficient than direct subsidies for stimulation of individual behaviour in the direction of the achievement of certain purposes [26]. Acknowledging the importance of the estimation of tax relief efficiency on the national and sub-national levels, let it be noted that the author does not investigate this problem in this work. The estimation of tax relief efficiency in Russian conditions requires in-depth and individual investigation.

In scientific works on the problems of tax planning at the microlevel, numerous definitions of tax planning are contained, the place of tax planning in the system of management of organizations is specified, a role of different structural subdivisions in tax planning is shown, different models and methods of optimization and minimization of taxation are projected.

At the same time it is necessary to note that the problem of tax planning at the level of economic entities is considered by the above-mentioned authors mainly from the perspective of practical recommendations to accountants and tax consultants, explaining the methods of decrease of tax payments. Theoretical and methodical justification ofprinciples and methods of tax planning, formulation of scientific methodology of tax planning organization, and the identification of its place in the system of general economic planning pale into insignificance, because tax planning cannot be efficient without the availability of established and recognized principled foundations and institutional conditions, the formation of instruments and the methods of investigation.

In addition to its empirical orientation to decrease tax returns, modern practice of tax planning organization also differs from the standards acknowledged abroad, by the excessively significant role of an organization's accounting department in this area of planning and the insignificant role of economic and financial services. The latter either do not take participation in tax planning at all, or they collect statistical information.

Now, therefore, planning of tax payments by Russian organizations in modern times can become one of the most important options of their management.In these days tax planning, unfortunately, does not have theoretical justification and is applied in practice only to decrease tax payments to the federal, regional and local budgets of the Russian Federation, without considering existing functional relations, and has a random nature.

For example, tax planning at the micro-level is understood to be "“organization of entrepreneurial and/or private activity of a person with the lowest tax consequences' [27], "organization of activities of enterprises in such a way as to minimize tax liabilities for a stable period, not violating the letter and spirit of legislation" [28], "a complex of planned measures aimed to increase financial resources of organizations, regulating volume and structure of the taxation base, affecting efficiency of managerial decisions and providing well-timed settlements with the budget in accordance with legislation in effect" [29]," a legal method of tax minimization by use of tax relief and options of reduction of tax liabilities provided by law" [9], "a legal method of evasion of taxation by use of tax relief and options of reduction of tax liabilities provided by law" [8].

Russian scientist and economist, Doctor of Economics, Professor E.S. Vylkova, proposes to make a distinction between tax planning on the level of an economic entity as a wider conception and tax planning as a narrower conception [17]. Researcher D. Yu.Zhidkova considers that tax plan- 
ning sets a purpose to minimize tax payments by legal methods based on the application of tax relief and preferences, the correct selection of tax regimes and taxation objects, reasonable formation and use of accounting policy components [30].

As the investigation shows, many famous Russian and foreign scientists mean by tax planning — first and foremost - activities aimed to decrease tax payments. The proposed definitions consider the essence of tax planning from purely restrictive positions, perceiving it through the prism of confrontation of a taxpayer on one side and fiscal authorities on the other side.

At the same time, tax planning serves not only and not that much to decrease the tax payments of organizations, although optimization of a tax portfolio represents its most important function, to become a regulator of the process of organization management in addition to the business plan. Minimization and optimization of a tax portfolio does not always meet the strategic needs of an economic entity. In accordance with the taxation practice existing in the Russian Federation, it is unprofitable for an economic entity to understate the taxation base in certain cases, for example, in the cases when the cost of minimization of tax payments exceeds revenues from it, as well as when relief from payment of one tax can result in the increase of taxes in regard to other tax payments. Responsible executives of organizations and corporations can refuse tax minimization by virtue of social and political reasons as well. Refusal to minimize taxation in the specified cases does not mean refusal to apply tax planning; on the contrary, tax planning stays, as before, one of the main types of general economic planning (specialists of the organization keep studying and analysing effective tax legislation, perform tax calculations, and draw up a tax calendar).

Thus, tax planning on the level of an economic entity, in the author's opinion, represents a complex multi-dimensional and multi-aspect integration process, lying in the arrangement of financial and economic activity of an economic entity, in accordance with the strategy of organizational development in the frames of effective tax legislation.

The full uncovering of the economic content of tax planning, on the basis of a complex and systematic approach, develops and supplements the theory and methodology of taxation management. The identification of essential characteristics and the proposed definitions of tax planning at the macroand micro-levels are the most important institutional conditions of improvement of its efficiency at the present stage of the Russian Federation.

\section{References}

1. Yutkina T.F. Taxes and taxation.-M.: INFRA-M, 1998-P. 148

2. Romanovsky M.V., Vrublevskaya O. V. Budget system of the Russian Federation.-M., URAIT, 2005.- P. 125.

3. Karbushev G. I., Zimin V. M. Improvement of the tax system of Russia. // Ekonomika i zhizn, 2000.- No. 2.- P. 58

4. Vinslav Yu.M. Financial management in large corporate structures. // Rossiysky ekonomichesky zhurnal, 1998. No. 3.- P. 43.

5. Great Economy Encyclopaedia. / Under the editorship of A. Ya.Sukharev.-3rd edition, revised and enlarged.- M.: INFRA - M., 2007.- P. 123.

6. Friedman Jack P. Dictionary of Business Terms. / Barron's Educational Series, Inc., 2000.— $736 \mathrm{p}$

7. Bodie E., Merton R. Finances.- M., Williams Publication House, 2009.- P. 38.

8. Ponamarev A. I., Ignatova T. V. Tax administration in the Russian Federation.- M. "Finansy $i$ statistika", 2006

9. Tax administration. / Under the editorship of L. I. Goncharenko.—M.: "Knorus", 2009.— P. 180.

10. Musgrave Richard A., Musgrave Peggy B. Public Finance in Theory and Practice. / Translation form English. M.: Business Atlas, 2009.- P. 319 
11. Samuel Brown and William Gale. Tax reform for growth, equity, and revenue. // Urban -Bookings Tax Policy Center. November 30, 2012. P. 5-12.

12. Official information from the website of the Federal Tax Service of the Russian Federation: www.nalog.ru. URL: http://www.nalog.ru/nal_statistik/statistic/budjet/ (date of visit 01/08/2013).

13. Musaeva Kh.M. Formation and development of tax federalism in the Russian Federation: problems and prospects. 2012-№ 4 (94) - p. 85

14. Tikhonov D. N. Fundamentals of tax planning.- M., 1999.- P. 178.

15. Valente P. Enhanced Cross-border Cooperation against Aggressive Tax Behaviours. An Outlook on International Tax Initiatives / P. Valente / The $5^{\text {th }}$ European Conference on Tax Advisers Professional Affairs. - London, 7 Dec. 2012.

16. Busse R. International cooperation at struggle with tax evasion: experience of the European Union. // Scientific works of the Scientific and Research Financial Institute. - Kiev, 2013.No. 1 (60) -P. 123.

17. Vylkova E. S. Tax planning.- M.: Urait, 2012.- P. 26.

18. Guskov S. Taxes in the economy of enterprises.- M.: Dashkov and Co., 2001.- P. 67-70.

19. Zhidkova E. Yu. Tax planning and taxation system improvement as components of development of entrepreneurial sector of economy in the Russian Federation. // Economic analysis: theory and practice.-2008, No. 3-P. 33.

20. Melnik D.A. Tax management.- M.: Finansy i statistika, 1999.- P. 123.

21. Rogozin B.A. Tax planning at enterprises and in organizations (optimization and minimization of taxation). The $7^{\text {th }}$ edition, in 3 vol.- M., 1997.- P. 234

22. Sidorova E. Yu. Tax planning.-M.: "Eksamen", 2006.— P. 20.

23. Seliutin K. S. Analysis of statistical planning for the value added tax. // Ekonomicheskie i gumanitarnye nauki, 2012.- No. 2.- P. 23.

24. Chernik D. G., Pochinok A. P., Morozov V.P. Fundamentals of a taxation system: Study guide for higher educational institutions. / Under the editorship of D. G. Chernik.- M.: Finansy, UNITI, 2003.- P. 200

25. Economy of taxation reforms. / Under editorship of I.A. Mayburov, Yu.B.Ivanov, L. L. Tarangul. Monograph.- Irpen, Kiev, "Alerta", 2013.— P. 227.

26. Tax Administration in OECD and Selected Non-OECD Countries: Comparative Information Series (2010) / OECD. URL: http://www.oecd.org. Date of visit: 28/08/2013.

27. Fundamentals of tax law. / Under the editorship of S. G. Pepeliaev.- M., 1998.— P. 96.

28. Tax and taxation. / Under the editorship of I.A. Rusakova, V.A. Kashin.- M.: "UNITI", 1998.- P. 96.

29. Kozenkova T. I. Tax planning. // Ekonomica i zhisn, 2005. - No. 17.- P. 23.

30. Musaeva Kh. M. Imanshapiyeva M. M. Systems of the taxation of subjects of small business: experience of the industrial countries and possibility of its use in the conditions of the Russian Federation. Taxes and taxation. 2011. No. 8.- P.23 